\title{
Assessment of ground water contamination by various pollutants from sewage water in Chakera village, Faisalabad
}

\author{
Faisal Iqbal, Shafaqat Ali, Hafiz Muhammad Tauqeer, Muhammad Bilal Shakoor, \\ Mujahid Farid, Usman Iftikhar, Muhammad Mudassir Nazir
}

Department of Environmental Sciences, Government College University Allama Iqbal Road, 38000, Faisalabad, Pakistan

\author{
Email address: \\ shafaqataligill@yahoo.com(S. Ali )
}

To cite this article:

Faisal Iqbal, Shafaqat Ali, Hafiz Muhammad Tauqeer, Muhammad Bilal Shakoor, Mujahid Farid, Usman Iftikhar, Muhammad Mudassir Nazir. Assessment of Ground Water Contamination by Various Pollutants from Sewage Water in Chakera Village, Faisalabad. International Journal of Environmental Monitoring and Analysis. Vol. 1, No. 5, 2013, pp. 182-187. doi: 10.11648/j.ijema.20130105.13

\begin{abstract}
The wastewater used for irrigation purposes affects the groundwater quality and hence the local community of Pakistan. Field study was conducted in Chakera Village, Faisalabad and the analytical work was performed in Biochemistry Laboratory, Soil and water sample were collected in two surveys in a month on fifteen days basis with three replica of each sample. Samples were analyzed for quality parameters like pH, EC, TDS, TSS, Carbonate, Bicarbonates, Chloride and Nitrates. Results of the study revealed that untreated wastewater application raised the values of EC,TDS, Chloride and Nitrates when compared with world Health Organization (WHO). This not only degrades soil structure but also contaminates the groundwater causing severe health hazard to the local community. Carbonates and Bicarbonates were found within the permissible range.
\end{abstract}

Key words: Carbonates, EC, Irrigation, TDS

\section{Introduction}

All forms of life on earth draw their prolong and growth from nature's most rich and free available reserve of water. Water is essential for life. Humans, animals, and plants all need water to live and to rise. But in many parts of the world humans have no access to the clean drinking. Water is polluted with germs, worms, or toxic chemicals and this can lead to many illnesses [1]. In developing countries, about $80 \%$ of urban wastewater is used for irrigation paying to $70-80 \%$ food security and livelihood of urban and peri-urban communities [2]. It has been estimated that $64 \%$ of total wastewater of Pakistan is disposed of either into river or into Arabian Sea. Similarity, 400,000 $\mathrm{m}^{3} /$ day are moreover added to canal [3].

In Pakistan 32500 ha land is being irrigated with city effluent [3]. Such irrigation practices provide crop yield as it contains large amount of organic material and in organic minerals essential for crop growth [4]. Nitrate in groundwater sources from extreme use of chemical fertilizer, uncontrolled on land discharge of municipal and industrial wastewater, human and animal waste run off septic tank and processed food [5].
Nitrate ion is stable and extremely soluble in water and can easily move through soil into aquifer [6]. This property makes it difficult to remove it using conventional water treatment technology. The ion exchange process seems to be suitable for small water supplier's contamination by nitrate, because of its simplicity, effectiveness, selectivity, improvement and relatively low cost [7]. According to WHO (World Health Organization), drinking water must contain nitrate not more than $50 \mathrm{mg} / \mathrm{L}$ [8]. Nitrate from drinking water account for $15-75 \%$ of person exposure to nitrate from environmental sources [9].

Nitrate in drinking water may be associated with increased risk of bladder and ovarian cancer, genotoxic at chromosomal level and insulin dependent diabetes [10].

The comparative study was carried out in two peri-urban villages close to the city of Faisalabad while farmers in KehalaVillage used predominantly ground water to irrigate their fields; the groundwater in neighboring Chakera was too saline for use in agriculture. Instead, farmers they used untreated wastewater diverted from the feeding canal of the nearby Wastewater Stabilization Ponds [11].

In this regards different parameters of waste water samples were analyzed to check the contamination level 
affecting the ground water quality

\section{Materials and Methods}

All analytical work was performed in the Biochemistry Laboratory, Soil and Environmental Section, Ayyub Agriculture Research Institute, Faisalabad.

Total 6 Ground water samples were collected two times in a month on fifteen days basis with three replicates of each site from Chakera village.

WHO standard values for drinking water are used for comparison WHO (2004) [12]. Analytical chemical grades were used for reagents preparation.

The electrode is calibrated with standard buffer solution of 7.0 and $9.0 \mathrm{pH}$ by using potentiometer method [13].

The $\mathrm{pH}$ of ground water samples were measured by an electronic $\mathrm{pH}$ meter (3510 pH meter Jenway).

Electrical Conductivity was measured directly by conductivity meter (4510 conductivity meter Jenway). It used to determine the soluble salt in the sample at particular temperature. EC is normally double then that of Total Dissolved Solids [13].

The Silver Nitrate Method was used for chloride determination. Silver nitrate was used as titrant and potassium chromate as an indicator. The silver nitrate reacted with all the chloride, form silver chloride formed and free nitrate ions. Once all chlorides present in the sample have been complexes, excess silver ions combine indicator to form brick red colored complex [13].

$$
\begin{array}{lc}
\text { Silver Nitrate } & 0.05 \mathrm{~N} \\
\text { Potassium chromate } & 10 \% \\
\text { Calculations } & \\
\mathrm{Cl}^{-} \mathrm{me} / \mathrm{l}= & \underline{\mathrm{V} \times 0.05 \mathrm{~N} \times 1000} \\
\cline { 2 - 2 } & \text { Volume of sample used }
\end{array}
$$$$
\text { From where }
$$

$\mathrm{N}=$ Normality of silver nitrate solution

$\mathrm{V}=$ volume of sliver nitrate solution used

Carbonates and Bicarbonates were determined by

\begin{tabular}{|c|c|}
\hline $\mathrm{H}_{2} \mathrm{SO}_{4}$ & $0.1 \mathrm{~N}$ \\
\hline Phenolphthalein & $0.5 \%$ \\
\hline Methyl orange & $0.1 \%$ \\
\hline \multicolumn{2}{|l|}{ Calculations } \\
\hline \multirow[t]{2}{*}{ Carbonates meq $/ \mathrm{L}=$} & $\underline{2 \times V \times 0.1 \mathrm{~N} \times 1000}$ \\
\hline & Volume of sample used \\
\hline \multicolumn{2}{|c|}{ Bicarbonates meq $/ \mathrm{L}=\left(\underline{\mathrm{V}}_{2}-\mathrm{V}_{1}\right) \times 0.1 \mathrm{~N} \times 1000$} \\
\hline & Volume of sample used \\
\hline \multicolumn{2}{|l|}{ From where } \\
\hline \multicolumn{2}{|c|}{$\mathrm{N}=$ Normality of sulphuric acid } \\
\hline \multicolumn{2}{|c|}{$\mathrm{V} 1=$ Volume of a titrant against phenolphthalein } \\
\hline $\mathrm{V} 2=$ Volume of a titı & at against methyl orange indicator \\
\hline
\end{tabular}
titrating $10 \mathrm{ml}$ samples water against standard $0.1 \mathrm{~N} \mathrm{H}_{2} \mathrm{SO}_{4}$. The end point for carbonates was pink color while for Bicarbonates was red color. The method used phenolphthalein and methyl orange as an indicator [13].
The electrode were calibrate with standard solution of $\mathrm{KNO}_{3}$ [14].

The value of heavy metals from ground water samples was estimated by atomic absorption spectroscopy (AAS 5500). Prior to analysis samples were acidified with N/10 $\mathrm{HNO}_{3}$ standard solution and blanks were run at the time of analysis, absorbance/concentration were measured [15].

\section{Results and Discussions}

$\mathrm{pH}$ value of ground water samples in $1^{\text {st }}$ survey and $2^{\text {nd }}$ survey and their comparison with WHO standards are shown in fig 1 . In $1^{\text {st }}$ survey $\mathrm{pH}$ value in sample 1 was 7.1 , second sample had value 7.21 and $3^{\text {rd }}$ sample showed 7.53 value of $\mathrm{pH}$. Similarly in $2^{\text {nd }}$ survey $\mathrm{pH}$ value of ground water sample 1 was recorded 6.92, second sample had value 7.3 and $3^{\text {rd }}$ sample showed 7.6 value. The comparison between $\mathrm{pH}$ value of $1^{\text {st }}$ and $2^{\text {nd }}$ survey showed that $\mathrm{pH}$ values of all ground water samples were almost similar. It was also investigated that $\mathrm{pH}$ values of all ground water samples in both surveys were below WHO standards (6.58.5).

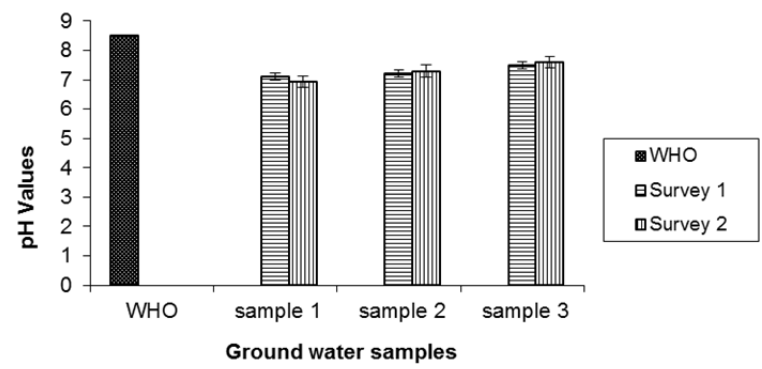

Figure 1. Comparison of $\mathrm{pH}$ value of ground water samples from Chakera Village, Faisalabad between two surveys

EC values of ground water samples were recorded as $3.46 \mathrm{dS} / \mathrm{m}, 3.17 \mathrm{dS} / \mathrm{m}$ and $2.86 \mathrm{dS} / \mathrm{m}$ during $1^{\text {st }}$ survey. EC value of all ground water samples was higher than WHO standards $(3 \mathrm{dS} / \mathrm{m})$ as shown by the Fig. 2 . Similarly in $2^{\text {nd }}$ survey EC values of $3.86 \mathrm{dS} / \mathrm{m}, 3.50 \mathrm{dS} / \mathrm{m}$ and $3.17 \mathrm{dS} / \mathrm{m}$ were obtained during the analysis. All samples of ground water were showing higher values than WHO standards (3 $\mathrm{dS} / \mathrm{m})$.

By comparing the EC values of ground water samples in $1^{\text {st }}$ survey to $2^{\text {nd }}$ survey, the EC values of $1^{\text {st }}$ survey was lower than the $2^{\text {nd }}$ survey values, Faisalabad (fig. 4.2).

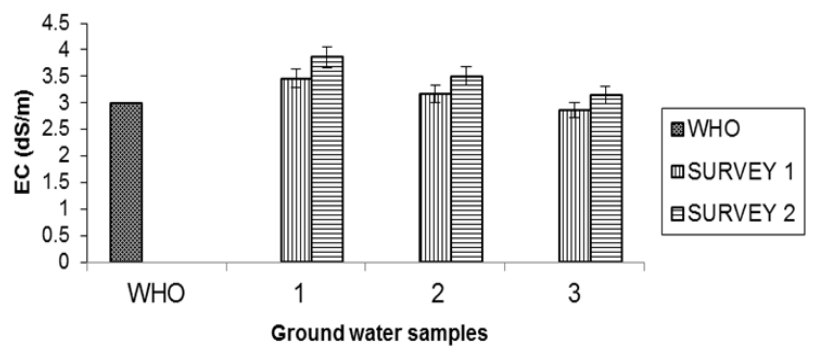

Figure 2. Comparison of EC values of ground water samples from Chakera Village, Faisalabad between two surveys 
TDS values of ground water samples were recorded as $2318 \mathrm{mg} / \mathrm{L}, 2123 \mathrm{mg} / \mathrm{L}$ and 1916 respectively during the $1^{\text {st }}$ survey. TDS values of all ground water samples were higher than the WHO standards. (1000 mg/L) (Fig. 3).TDS value of ground water sample 1 was $2586 \mathrm{mg} / \mathrm{L}$; second sample had the TDS value of $2345 \mathrm{mg} / \mathrm{L}$ and the $3^{\text {rd }}$ sample showed the value of $2110 \mathrm{mg} / \mathrm{L}$. TDS values of all ground water samples were below than WHO value during the $2^{\text {nd }}$ survey (1000 mg/L) (Fig. 3).

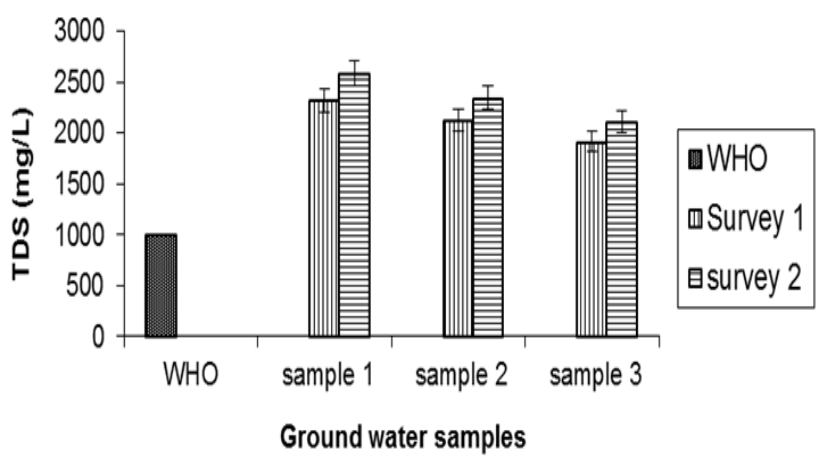

Figure 3. Comparisons of TDS values of ground water sample from Chakera Village, Faisalabad between two surveys

In Fig 4 the values of TSS (mg $\mathrm{l}^{-1)}$ for ground water samples in $1^{\text {st }}$ survey and $2^{\text {nd }}$ survey and their comparison with WHO standards are explained. In $1^{\text {st }}$ survey TSS value in sample 1 was $2214 \mathrm{mg} \mathrm{L}^{-1}$, second sample had value $2028 \mathrm{mg} \mathrm{L}^{-1}$ and $3^{\text {rd }}$ sample showed $1830 \mathrm{mg} \mathrm{L}^{-1}$ value of TSS. Similarly in $2^{\text {nd }}$ survey TSS value of ground water sample 1 was recorded $2470 \mathrm{mg} \mathrm{L}^{-1}$, second sample had value $2240 \mathrm{mg} \mathrm{L}^{-1}$ and $3^{\text {rd }}$ sample showed $2028 \mathrm{mg} \mathrm{L}^{-1}$ value. The TSS value of ground water samples in $1^{\text {st }}$ survey was relatively lower than the $2^{\text {nd }}$ survey value. By comparing the TSS value of ground water sample 1 in $1^{\text {st }}$ survey to $2^{\text {nd }}$ survey, the value of TSS was lowered in $1^{\text {st }}$ survey than the $2^{\text {nd }}$ survey, similar results showed $2^{\text {nd }}$ and $3^{\text {rd }}$ sample of ground water of Chakera Village, Faisalabad.

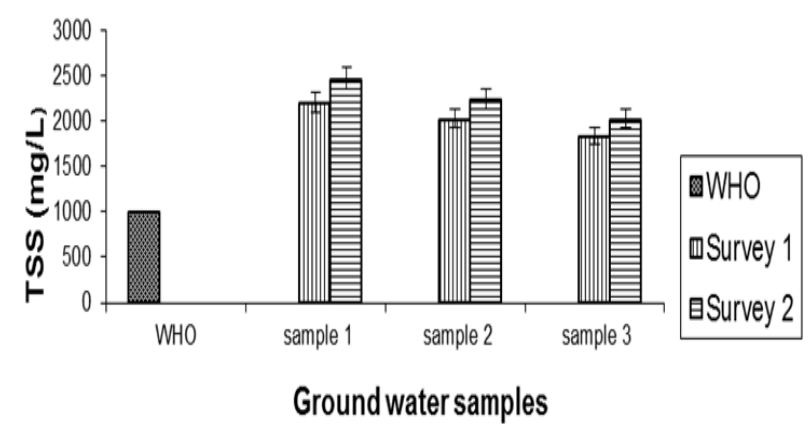

Figure 4. Comparison of TSS values of ground water samples from Chakera Village, Faisalabad between two surveys

In Fig 5 the values of Chlorides meq/L for ground water samples in $1^{\text {st }}$ survey and $2^{\text {nd }}$ survey and their comparison with WHO standards are discussed . In $1^{\text {st }}$ survey Chlorides value for ground water sample1 taken 7 feet away from main sewage drain of Chakera village, Faisalabad was 17 meq/L, second sample that was taken 200 feet from sewage drain was $15 \mathrm{meq} / \mathrm{L}$ and third sample that was taken away 300 feet from sewage drain showed $14 \mathrm{meq} / \mathrm{L}$.) While the Chlorides value of ground water sample 1 in $2^{\text {nd }}$ survey was $17.5 \mathrm{meq} / \mathrm{L}$, second sample had value $16 \mathrm{meq} / \mathrm{L}$ and $3^{\text {rd }}$ sample showed $15.50 \mathrm{meq} / \mathrm{L}$ values. The results shows that all samples values in survey $1^{\text {st }}$ and $2^{\text {nd }}$ are higher than of WHO (7.04 meq/L) standard and the values of survey $2^{\text {nd }}$ is higher than of survey $1^{\text {st }}$ in all samples.

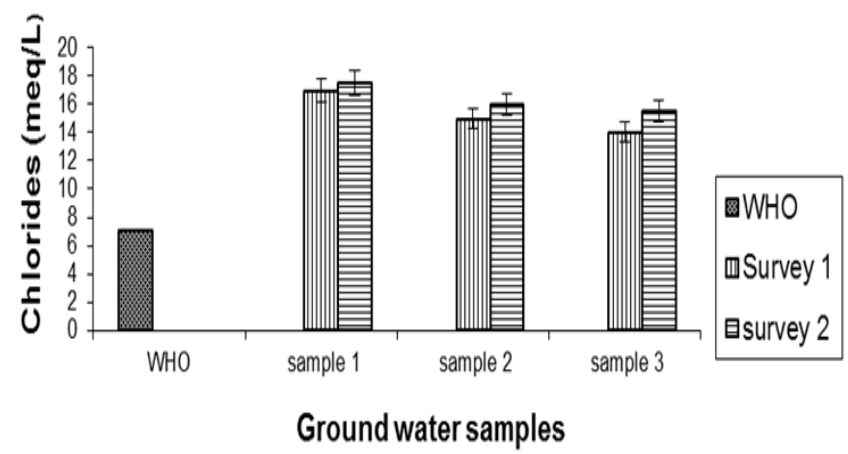

Figure 5. Comparison of Chlorides values of ground water samples from Chakera Village, Faisalabad between two surveys

In Fig 6 the values of carbonates and bicarbonates (meq $1^{-1)}$ for ground water samples in $1^{\text {st }}$ survey and $2^{\text {nd }}$ survey and their comparison with WHO standards is explained. The analytical study showed Carbonates and Bicarbonate value for ground water sample1 taken 7 feet away from main sewage drain of Chakera village, Faisalabad was 2.5, $1.25 \mathrm{meq} / \mathrm{L}$, second sample that was taken 200 feet away had $2,1 \mathrm{meq} / \mathrm{L}$ and third sample that was taken 300 feet away was $1,0.5 \mathrm{meq} / \mathrm{L}$. Similarly in $2^{\text {nd }}$ survey Nitrates value of ground water sample 1 was 5 and $2.5 \mathrm{meq} / \mathrm{L}$ Carbonates \& Bicarbonates value, second sample showed 3.2 and $1.6 \mathrm{meq} / \mathrm{L}$ and $3^{\text {rd }}$ sample had 2.5 and $1.3 \mathrm{meq} / \mathrm{L}$. in both surveys the values were within the WHO $(8.5 \mathrm{meq} / \mathrm{L}$ limits and the values were higher in $2^{\text {nd }}$ survey than of $1^{\text {st }}$ survey.

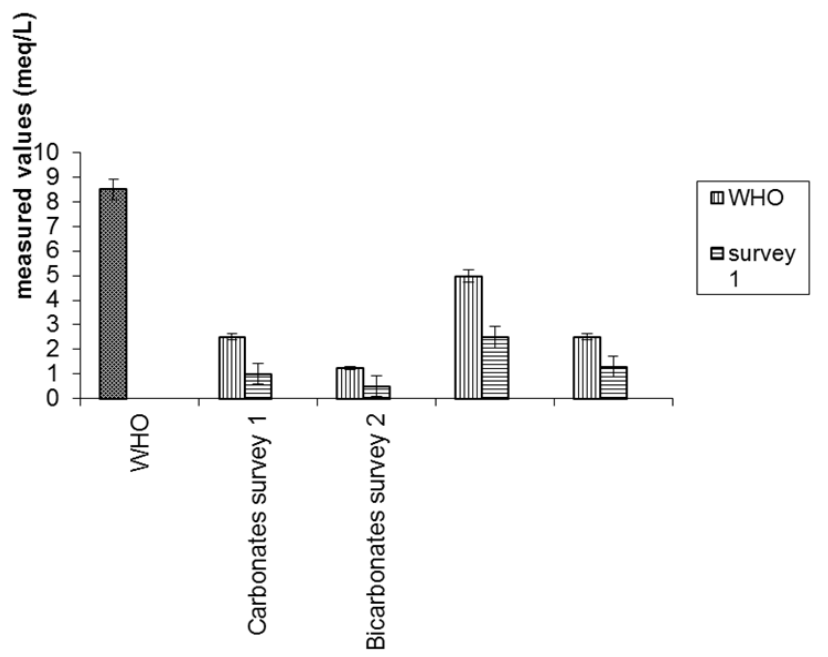

Figure 6. Comparison of carbonates and Bicarbonates values of ground water samples from Chakera Village, Faisalabad between two surveys 


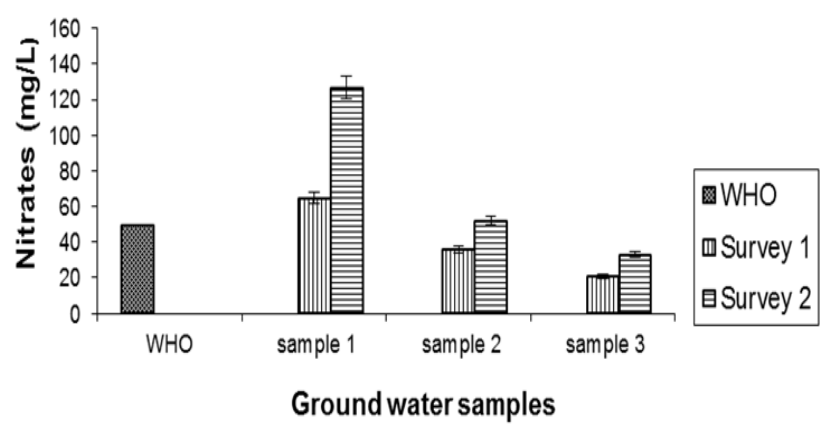

Figure 7. Comparison of Nitrates values of ground water samples from Chakera Village, Faisalabad between two surveys with WHO standards is explained The analytical study showed that nitrate value for sample 1 that was taken 7 feet away from sewage drain was $65 \mathrm{mq} / \mathrm{L}$, second sample that was taken 200 feet away had $36 \mathrm{mg} / \mathrm{L}$ and third sample that taken 300 feet away showed $21 \mathrm{mg} / \mathrm{L}$.. Similarly in $2^{\text {nd }}$ survey Nitrates value of ground water sample 1 was 127 $\mathrm{mg} / \mathrm{L}$, second sample had value $52 \mathrm{mg} / \mathrm{L}$ and $3^{\text {rd }}$ sample showed $33 \mathrm{mg} / \mathrm{L}$ value. In 1 st sample of survey $1^{\text {st }}$ and $2^{\text {nd }}$ the nitrated values were higher than of WHO standard while in other two samples of both surveys were in limits And the values of survey $2^{\text {nd }}$ was all the time higher than of $1^{\text {st }}$ survey.

In Fig 7 the values of Nitrates $\left(\mathrm{mg}^{-1)}\right.$ for ground water samples in $1^{\text {st }}$ survey and $2^{\text {nd }}$ survey and their comparison

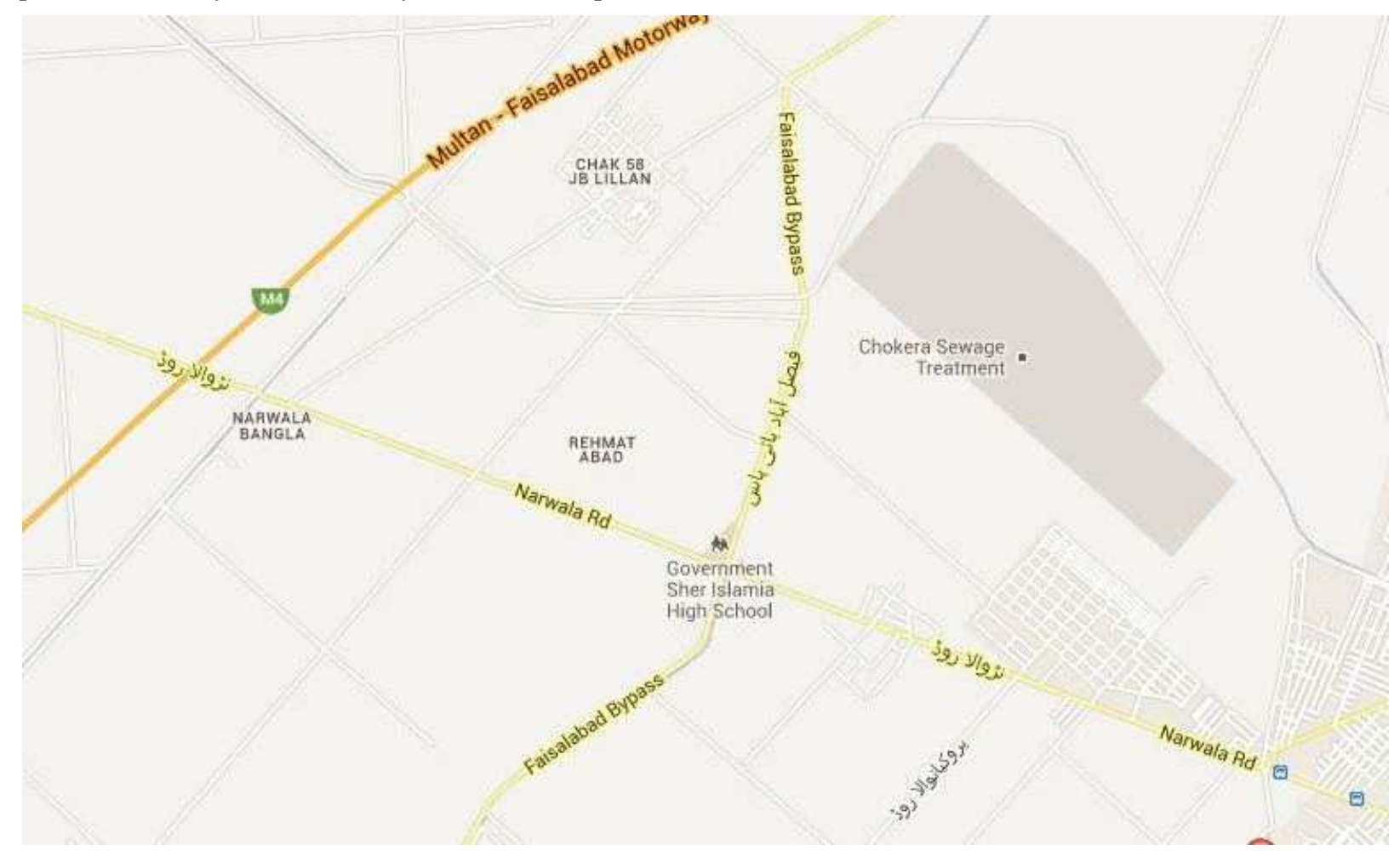

Figure 8. Pictorial view of Chokera Sewage Treatment Plant Faialabad

\section{Discussion}

$\mathrm{pH}$ usually has direct effects on biotic environment. For satisfactory water disinfection and clarification at all stages the control of $\mathrm{pH}$ is very necessary. Effective disinfection with chlorine, the $\mathrm{pH}$ should preferably be less than 8 [16].

The present study is in accordance with the work of Zakiullah [17] which indicated the $\mathrm{pH}$ value of ground water in range of 6.44-7.27.

Salty taste is aesthetic effects of EC if it exceeds 150 $\mathrm{mS} / \mathrm{m}$ and if greater than $300 \mathrm{mS} / \mathrm{m}$ it does not satisfy the thirst [18]. Results of this study related to the Phirio [19] study who assessed the extent of pollution in rivers which were affected by textile effluent and sewage water in Malawi.

The present study was in relation to Increase in the conductivity of ground water than National Environment Quality Standards was due to injection of polluted water into it [20].

Salinity of water is due to presence of high TDS concentration and its value above $500 \mathrm{mg} / \mathrm{l}$ is not suggested for drinking purposes [21]. Craun et al. [22] were reported that increase TDS concentrations in drinking water cause of cancer, coronary heart disease, arteriosclerotic heart disease and cardiovascular disease.

High chloride content in water bodies harms metallic pipe and pictures as well as agriculture crops. The present research linked with Asim and Khan [23] research. Their studied were to characterize the combined effect of industrial and municipal wastewater in Paharang Drain. Results showed that chloride concentrations were significantly higher as compared to National Environmental 
Quality Standards (NEQS).

Hardness levels above $500 \mathrm{mg} / \mathrm{L}$ are generally considered to be aesthetically unacceptable, although this level is tolerated in some communities [24].Hardness of drinking-water cause cardiovascular disease [25]. The present study correlated with Ashraf et al [21] research. They determined the effect of using polluted water for irrigation on quality of ground water. The result showed that the value of Carbonates and Bicarbonates of ground water samples from Chakera, Faisalabad was not in increase than WHO standard.

The point source of nitrogen compound in ground water is household sewage [26].Nitrate itself is not a poisonous substance, and it is not a problem for adults but it is very dangerous for infants under six months of age because it cause methemoglobin [27]. The nitrogen level in groundwater should not exceed $10 \mathrm{mg} / \mathrm{L}$ as $\mathrm{N}$ or $50 \mathrm{mg} / \mathrm{L}$ as nitrate $\left(\mathrm{NO}_{3}\right)$ [12]. Behnke [28] determined that surface sources of ground water nitrate contamination related to man's activities include domestic sewage, agricultural practices, and high-density animal confinement. Chen et al [29] studied the nitrate contamination of ground water by waste water irrigation of Shijiazhuang, China. Their resulted showed that the value of nitrate in ground water increase as compared to WHO standard.

\section{Conclusion}

- The concentration of elements (EC, TDS, TSS, Nitrates and Chlorides) was more than the standard values in the sample that taken near to the sewage drain that might be due to the sewage water.

- The carbonates, bicarbonates and heavy metals values were within the permissible limits in all ground water samples because these elements remained in the soil.

\section{References}

[1] J. Conant, "Water for Life Community water security", 2005, pp. 3-4.

[2] D. Mara, and S. Cairncross, "Guidelines for the safe use of waste water and excreta in agriculture and aquaculture", World Health Organisation, Vol. 1,1989.

[3] J.H. Ensink, T. Mamood, V.D. Hoek, R.L.Sally and F.P. Amerasinghe," A Nationwide assessment of Wastewater Use in Pakistan: an obscure activity or a vitally important one", Water policy, Vol. 6,2004, pp. 1-10.

[4] A. Mitra, and S.K. Gupta, "Effect of sewage water irrigation on essential plant nutrients and pollutant element status in vegetable growing area around Calcutta," Journal of the Indian Society of Soil Science,Vol. 47, No.1, 1999, pp. 99105.

[5] S.Samatya, N. Kabay and M.A. Yuksel, 2006 "Removal of nitrate fromaqeous solution by nitrate selective ion exchange resins", Reactive and Functional Polymers Journal, Vol. 66, No. 11, 2006, pp. 1206-1214.

[6] A.Pintar, J. Batisa and J. Levec,"Integrated ion exchange process for efficient removal of nitrate from drinking water," Chemical Engineering Science Journal, Vol. 56, No. 4, 2001, pp. 1551- 1559 .

[7] B.Bae, Y. Jung, W. Han and H. Shin, 2002. "Improved brine recycling during nitrate removal using ion exchange," Water Research Journal, Vol. 36, No.13, 2002, pp. 3330-3340.

[8] N. Lohumi, S. Goasin, A. Jain, V.K.Gupta and K.K. Verma,"Determination of nitrate in Environmental water samples by conversion into nitro phenols and solid phase extraction spectrophotometry, liquid chromatography or gas chromatography-mass spectrometry," Analytica Chimica Acta, Vol. 505, No. 2, 2004, pp. 231-237.

[9] S. Vladeva, P. Gatseva and G. Gopina,"Comparative analysis of results from studies of goiter in children from Bulgarian villages with nitrate pollution of drinking water in 1995 and 1998," Central European Journal of Public Health, Vol. 8, No. 3, 2000, pp.179-181.

[10] M.H.Ward, S.D. Mark, K.P. Cantor, D.D. Weisenburger, C.A.Villasenore and S.H. Zahm, "Drinking water and the risk of non-Hodgkin's lymphoma," Epidemiology, Vol. 7, No.5, 1996, pp.465-471.

[11] P. Weckenbrock, W. Ahmad, M.Q. Majeed and M.N. Ashraf, "Conference on International Research on Food Security, Natural Resource Management and Rural Development, Tropentag" 2010.

[12] WHO. 2004.World Health Organization. URLhttp: // www.who.into/water_sanitation_health/dwq/GDWQ2004we b.pdf.

[13] United States Salinity Laboratory Staff., "Diagonsis and improvement of saline and alkali Soils," USDA Hand Book 60.US Department of agriculture, Washington DC, 1954, pp. 89-91.

[14] A.D. Eaton, L.S. Glesceri and E.W. Rice,"Standard method for the examination of water and wastewater," International Journal of Environmental Science and Technology, Vol. 4, 2005, pp. 122-123.

[15] Apha, "American Public Health Association, Standard Methods for the Examination of Water and Wastewater," Washington, 2005.

[16] M. Katyal, and M. Satake, 1990. 'Total Environmental Pollution”. Annual publication India, 1990, pp, 57-9.

[17] M.T. Zakiullah and A. Rashid, 1998 "Accumulation of heavy metals in water of River Soan due to effluent in industrial area," International Symposium Agro Environ Issues and Future strategies toward $21^{\text {st }}$ century, 1998, pp. 25-30.

[18] N.A. Memon, M.A. Umar, A.K. Ansari, G.B. Khaskaehli and B. Ahmad,"Predictive potentiality of artificial neural networks for predicting the electrical conductivity (EC) of drinking water of Hyderabad city," World Scientific and Engineering Academy and Society (WSEAS) Stevens Point, Wisconsin, USA, 2008, pp. 487-490.

[19] O. Phirio, P. Mumba, B.H. Zmoyo and W. Kadewa, "Assessment of the impacts of industrial effluents on water 
quality of receiving rivers in urban area," International Journal of Environmental Science and Technology, Vol.No.3, 2005, pp. 237-244.

[20] M.A. Ashraf, K. Mahmood, I. Yousff and A. Wajid,"Study of health and Environmental risks associated with polluted water irrigation," International Journal of Chemical Engineering and Applications, Vol. 2, No. 1, 2011, pp. 2631.

[21] T. Harter, "Groundwater quality and groundwater pollution.University of Calinfornia, Division of Agriculture and natural resources," 2003, pp. 1-5.

[22] G.F. Craun and L.J. Mccabe,"Problems associated with metals in drinking water. Journal of the American Water Works Association, Vol. 67, 1975, pp. 593.

[23] M.Asim and Z. Khan, 2006 "Physico-chemical monitoring of combined industrial and municipal effluents in paharang drain," Faisalabad.Institute of Environmental sciences and Engineering, National University Science and Technology, H-12 Islamabad, Pakistan, 2006, pp.52-59.

[24] B.C.J. Zoeteman, "Sensory assessment of water quality." Oxford, Pergamon Press, 1980.
[25] S.J. Pocock,"British regional Heart Study: geographic variations in cardiovascular mortality and the role of water quality," British Medical Journal, Vol. 280, No.6226, 1980, pp.1243-1249.

[26] G.E. Fogg, D.L. Rolston, D.T. Decker, Louie and Grismer, 1998 "Spatial variation in nitrogen isotope values beneath nitrate contamination sources," Ground water, Vol. 36, No. 3, 1998, pp.418-426.

[27] Y. Abumaila, I. El-Nahal and M.R. Al-Agha, "Seasonal variation and mechanisms of groundwater nitrate pollution in the Gaza Strip," Environmental Geology, Vol. 47, No.1, 2004, pp. 84-90.

[28] J. Behnke, 2003 "A summary of the biogeochemistry of nitrogen compounds in ground water," Journal of Hydrology, Vol.27, No, 1-2, 2003, pp.155-167.

[29] J. Chen, C. Tang and J. Yu, 2006 "Use of 18O, 2H and 15N to identify nitrate contamination of groundwater in a wastewater irrigated field near the city of Shijiazhuang China," Journal of Hydrology, Vol. 326, 2006, pp. 367-378. 